A N N A L ES

UNIVERSITATIS MARIAE CURIE-SKŁODOWSKA

LUBLIN - POLONIA

VOL. LXII, 1

SECTIO G

2015

PAULINA CHALA

Prokura jako szczególny rodzaj pełnomocnictwa

Commercial Representation as a Special Kind of Power of Attorney

\title{
WPROWADZENIE
}

Prokura jest instytucją z długim rodowodem. Jej początków należy szukać w prawie niemieckim, co nie powinno budzić zdziwienia, ponieważ w doktrynie uważa się Niemcy za kolebkę prawa handlowego. Swą genezą sięga Niemieckiego kodeksu handlowego (Handelsgesetzbuch - HGB) z 10 maja 1897 roku$^{1}$. Przepisy o prokurze znajdziemy w pierwszej księdze tego aktu, między innymi wśród przepisów o kupcach, rejestrach handlowych, firmie czy przedstawicielach. HGB można uznać za wzór, na którym oparła się polska regulacja prawna dotycząca tej instytucji. W Polsce początkowo prokura była uregulowana przepisami dekretu o rejestrze handlowym z dnia 7 lutego 1919 roku $^{2}$ oraz przepisami przełomowego w historii Kodeksu handlowego wydanego w formie Rozporządzenia Prezydenta Rzeczypospolitej Polskiej w dniu 27 czerwca 1934 roku$^{3}$, obowiązującego długo, bo aż do 31 grudnia 2000 roku. W dziale VI księgi I (art. 60-65), zatytułowanym „Pełnomocnicy handlowi”, zostały umieszczone przepisy dotyczące prokury. Art. 60 stanowił, iż prokury mógł udzielić tylko kupiec rejestrowy w formie pisemnego oświadczenia. Następcą prawnym Kodeksu handlowego jest obecnie obowiązujący Kodeks spółek handlowych (k.s.h.) z dnia 15 września 2000 roku Nie znajdziemy w nim jednak przepisów dotyczących prokury. Znalazły się one bowiem w innej ustawie - Kodeksie cywilnym (k.c.). Stało się tak na skutek no-

\footnotetext{
1 Ustawa z dnia 10 maja 1897 roku - Niemiecki kodeks handlowy (Handelsgesetzbuch).

2 Dekret z dnia 7 lutego 1919 roku o rejestrze handlowym (Dz.U. z 1919 roku, nr 14, poz. 164).

3 Rozporządzenie Prezydenta Rzeczypospolitej Polskiej z dnia 27 czerwca 1934 roku - Kodeks handlowy (Dz.U. z 1934 roku, nr 57, poz. 502).

4 Ustawa z dnia 15 września 2000 roku - Kodeks spółek handlowych (t.j. Dz.U. z 2015 roku, poz. 4).
} 
welizacji dokonanej ustawą o zmianie ustawy - Kodeks cywilny oraz niektórych innych ustaw z dnia 14 lutego 2003 roku , która weszła w życie 25 września 2003 roku. Pomimo zmiany umiejscowienia instytucji w innej ustawie, nadal zachowała ona charakter i kształt, jaki nadał jej Kodeks handlowy z 1934 roku, tj. jako szczególne pełnomocnictwo handlowe.

\section{DEFINICJA PROKURY}

Wspomniana wyżej nowela z 2003 roku wprowadziła instytucję prokury do Kodeksu cywilnego na stałe, gdyż stan ten utrzymuje się do dziś. Zmiana zapoczątkowała wysyp problemów związanych z określeniem charakteru prokury i skutkami prawnymi z tym związanymi. Zanim przejdziemy do omówienia tych problemów zostanie podjęta próba wyjaśnienia definicji oraz podstawowych zagadnień związanych z instytucją prokury.

Ustawodawca unormował prokurę przepisami zawartymi w dziale VI Kodeksu cywilnego, zatytułowanym „Przedstawicielstwo”, w rozdziale III tego działu zatytułowanym „Prokura”. Poprzedzający ją rozdział II, pt. „Pełnomocnictwo”, nasuwa wniosek, iż prokura należy do szeroko rozumianego przedstawicielstwa, szczególnego rodzaju pełnomocnictwa, nieobejmującego jednak zakresem całości jego regulacji ${ }^{6}$. Podobnie twierdzi J. Szwaja. Argumentuje, iż unormowanie pełnomocnictwa i prokury w odrębnych rozdziałach mogłoby uzasadniać ich równorzędną pozycję. Nie może mieć to znaczenia decydującego, bowiem pojęcie prokury mieści się w pojęciu pełnomocnictwa, co wskazuje, iż pełnomocnictwo pozostaje w relacji nadrzędności w stosunku do prokury. W związku z tym, idąc myślą J. Szwai, można sformułować wniosek, iż każda prokura jest pełnomocnictwem, ale nie każde pełnomocnicto jest prokurą ${ }^{7}$. Prokura jest szczególnego rodzaju pełnomocnictwem o ustawowo określonym zakresie umocowania. Potwierdza to art. $109^{1}$ Kodeksu cywilnego, w którym zapisane jest, iż prokura jest pełnomocnictwem udzielonym przez przedsiębiorcę podlegającego obowiązkowi wpisu do rejestru przedsiębiorców, które obejmuje umocowanie do czynności sądowych i pozasądowych, jakie są związane z prowadzeniem przedsiębiorstwa. Przytoczony przepis zawiera definicję legalną prokury, która w mojej opinii nie jest doskonała, ponieważ zawiera niejasności spowodowane wprowadzeniem pojęć niedookreślonych.

Po pierwsze, należy odpowiedzieć na pytanie, kto może udzielić prokury. Rozważania dotyczą więc jej aspektu podmiotowego. Ustawa przyznała legity-

5 Ustawa z dnia 14 lutego 2003 roku o zmianie ustawy - Kodeks cywilny oraz niektórych innych ustaw (Dz.U. z 2003 roku, nr 49, poz. 408).

6 A. Kidyba, Prawo handlowe, wyd. 13, Warszawa 2013.

7 J. Szwaja, Ustanowienie, udzielenie oraz odwołanie prokury przez spółkę handlowa, „Prawo Spółek” 2003, nr 7-8 s. 5. 
mację czynną przedsiębiorcy, ale nie ma jednej uniwersalnej definicji przedsiębiorcy. Występujące $\mathrm{w}$ różnych ustawach definicje przedsiębiorcy wprowadzają pewien chaos, ale można stwierdzić, iż ustawodawca, formułując przepisy o prokurze, miał na myśli definicję z art. $43^{1}$ Kodeksu cywilnego. W myśl tego przepisu przedsiębiorcą jest osoba fizyczna, osoba prawna i jednostka organizacyjna niemająca osobowości prawnej, której ustawa przyznaje zdolność prawną (o której mowa w art. $33^{1} \S 1$ k.c.), prowadząca we własnym imieniu działalność gospodarczą lub zawodową. Analizując art. $109^{1} \S 1$ k.c. w związku $\mathrm{z}$ art. $43^{1}$ k.c., można stwierdzić, iż prokury może udzielić tylko przedsiębiorca prowadzący działalność gospodarczą lub zawodową we własnym imieniu. Nie mógłby tego zrobić podmiot nieprowadzący takiej działalności. W doktrynie reprezentowane są jednak skrajne stanowiska dotyczące tego zagadnienia. A. Kidyba uważa, że spółka kapitałowa, która nie prowadzi działalności gospodarczej (trudno to sobie wyobrazić, ale istnieją spółki kapitałowe zakładane dla celów kulturalnych czy naukowych), nie może udzielić prokury, gdyż w świetle przepisów nie jest przedsiębiorcą. Nie ma przepisu szczególnego, który rozszerzałby stosowanie przepisów o prokurze na wszystkie spółki handlowe. Taka regulacja funkcjonowała na gruncie Kodeksu handlowego. W świetle art. 60 k.h. w zw. z art. 5 k.h. prokury mógł udzielić kupiec rejestrowy, tj. ten, kto prowadził przedsiębiorstwo zarobkowe w większym rozmiarze (art. 4 § 1 k.h.). Spółka handlowa była kupcem rejestrowym niezależnie od tego, czy prowadziła, czy nie prowadziła przedsiębiorstwa zarobkowego w większym rozmiarze ${ }^{8}$. Z kolei J. Szwaja wyraża przeciwny pogląd. Twierdzi, że spółka kapitałowa niespełniająca przesłanki prowadzenia działalności gospodarczej również może udzielić prokury ${ }^{9}$, ponieważ spełnia przesłanki z art. $109^{1}$ k.c.

Zakres uprawnionych do udzielenia prokury wyznacza nie tylko definicja przedsiębiorcy z Kodeksu cywilnego, ale także przepisy ustawy o Krajowym Rejestrze Sądowym. Te ostatnie nastręczają jednak szeregu wątpliwości związanych z użytymi tam pojęciami. Pierwsza wątpliwość dotyczy znaczenia terminu „rejestr przedsiębiorców”. Niejasności budzi kwestia istnienia w prawie polskim dualizmu w zakresie rejestracji przedsiębiorców. Obok rejestru przedsiębiorców prowadzonego przez Krajowy Rejestr Sądowy funkcjonuje Centralna Ewidencja i Informacja o Działalności Gospodarczej (CEIDG) dla osób fizycznych prowadzących działalność gospodarczą, którzy podlegają obowiązkowi wpisu do niej.

8 A. Kidyba, Nowe rozwiazania kodeksu cywilnego dotyczace prokury, [w:] Państwo - Prawo - Myśl prawnicza. Prace dedykowane prof. G.L. Seidlerowi w dziewięćdziesiąta rocznice urodzin, pod red. A. Korobowicza, Lublin 2003, s. 95.

9 J. Szwaja, [w:] S. Sołtysiński [et. al.], Kodeks spótek handlowych. Komentarz, t. 5, wyd. 2, Warszawa 2004, s. 491. 
Zgodnie z art. 36 ustawy o Krajowym Rejestrze Sądowym ${ }^{10}$ obowiązkowi wpisu do rejestru przedsiębiorców w Krajowym Rejestrze Sądowym podlegają:

- spółki jawne,

- europejskie zgrupowania interesów gospodarczych,

- spółki partnerskie,

- spółki komandytowe,

- spółki komandytowo-akcyjne,

- spółki z ograniczoną odpowiedzialnością,

- spółki akcyjne,

- spółki europejskie,

- spółdzielnie,

- spółdzielnie europejskie,

- przedsiębiorstwa państwowe,

- instytuty badawcze,

- przedsiębiorcy określeni w przepisach o zasadach prowadzenia na terytorium Rzeczypospolitej Polskiej działalności gospodarczej w zakresie drobnej wytwórczości przez zagraniczne osoby prawne i fizyczne (,przedsiębiorstwa zagraniczne"),

- towarzystwa ubezpieczeń wzajemnych,

- towarzystwa reasekuracji wzajemnej,

- inne osoby prawne, jeżeli wykonują działalność gospodarczą i podlegają obowiązkowi wpisu do rejestru stowarzyszeń, innych organizacji społecznych i zawodowych, fundacji oraz publicznych zakładów opieki zdrowotnej,

- oddziały przedsiębiorców zagranicznych działające na terytorium Rzeczypospolitej Polskiej,

- główne oddziały zagranicznych zakładów ubezpieczeń,

- główne oddziały zagranicznych zakładów reasekuracji,

- instytucje gospodarki budżetowej.

Niewłaściwe jest jednak ograniczenie kręgu podmiotów uprawnionych do udzielenia prokury do podmiotów zarejestrowanych w Krajowym Rejestrze Sądowym. Osoby fizyczne prowadzące działalność gospodarczą przecież również są przedsiębiorcami. Wynika to jednoznacznie z ustawy o swobodzie działalności gospodarczej oraz z Kodeksu cywilnego (art. $43^{1}$ k.c.). Co za tym idzie, osoby takie podlegają obowiązkowi wpisu do rejestru działalności gospodarczej, który pełni dla nich funkcję ,rejestru przedsiębiorców” z KRS. W związku z tym pojęcie „rejestr przedsiębiorców” użyte w art. $109^{1} \S 1$ k.c. oraz „właściwy rejestr”, o którym mowa w art. $43^{2}$ k.c., należy rozumieć szeroko. Tak samo uważa A. Ki-

10 Ustawa z dnia 20 sierpnia 1997 roku o Krajowym Rejestrze Sądowym (t.j. Dz.U. z 2015 roku, poz. 4). 
dyba, który przypisując rejestrowi znaczenie sensu largo, widzi w nim miejsce, w którym wpisywani są przedsiębiorcy niezależnie od nazwy rejestru nadanej przez przepisy szczególne regulujące zasady wpisów ${ }^{11}$.

Dodatkowym argumentem przemawiającym za rozumieniem rejestru w sensie largo jest to, iż w przepisach o prokurze (ściślej w art. $109^{1} \S 1$ k.c.) nie ograniczono wprost pojęcia rejestru przedsiębiorców do Krajowego Rejestru Sądowego. Takie rozwiązanie umacnia wykładnia celowościowa, ratio legis przepisów o prokurze oraz wykładnia historyczna. Nowelizacji Kodeksu cywilnego z 2003 roku towarzyszyła idea ujednolicenia sytuacji prawnej przedsiębiorców między innymi w zakresie prokury. Ograniczenie pojęcia rejestru przedsiębiorców, sprowadzające go wyłącznie do Krajowego Rejestru Sądowego, pozbawiałoby osoby fizyczne prowadzące działalność gospodarczą i będące przedsiębiorcami możliwości udzielenia prokury. Takie rozwiązanie na pewno kłóciłoby się z samą ideą nowelizacji. Warto wspomnieć, iż przepisom o prokurze wprowadzonym do Kodeksu cywilnego towarzyszyło, trwające od wielu wówczas lat, niezdecydowanie ustawodawcy, czy objąć rejestracją sądową przedsiębiorców będących osobami fizycznymi, czy nie ${ }^{12}$. W czasie opracowywania i wejścia w życie noweli Kodeksu cywilnego z 2003 roku nadal obowiązywał art. 36 pkt 1 ustawy o Krajowym Rejestrze Sądowym, zgodnie z którym w rejestrze przedsiębiorców Krajowego Rejestru Sądowego wpisywane miały być także osoby fizyczne prowadzące działalność gospodarczą. K. Kopaczyńska-Pieczniak w komentarzu do Kodeksu cywilnego pisze, że założeniem ustawy o Krajowym Rejestrze Sądowym było między innymi zlikwidowanie ewidencji działalności gospodarczej i ujednolicenie zasad rejestracji przedsiębiorców w Krajowym Rejestrze Sądowym niezależnie od tego, do jakiego rodzaju podmiotów są oni zaliczani. Niewątpliwie celem ustawodawcy było umożliwienie stosowania przepisów o prokurze również do przedsiębiorców indywidualnych (jednoosobowych), czyli osób fizycznych prowadzących działalność gospodarczą. Wątpliwości interpretacyjne pojawiły się dopiero, jak podaje autorka, na skutek nowelizacji ustawy - Prawo działalności gospodarczej, dokonanej ustawą z dnia 12 listopada 2003 roku, obowiązującej od dnia 1 stycznia 2004 roku, którą następnie uchylono art. 36 pkt 1 ustawy o Krajowym Rejestrze Sądowym i utrzymano ewidencję działalności gospodarczej. Wykluczono tym samym możliwość wpisu przedsiębiorców (osób fizycznych) do Krajowego Rejestru Sądowego. O ile więc w dacie wejścia w życie nowych przepisów o prokurze miał istnieć jeden rejestr przedsiębiorców, o tyle od dnia 1 stycznia 2004 roku istnieją dwa takie rejestry. Ponadto, co podkreśla autorka i z czym warto się zgodzić, nie wydaje się uzasadnione pozbawienie przedsiębiorców będących osobami fizycznymi możliwości udzielenia prokury. Najlepszym

\footnotetext{
11 A. Kidyba, Nowe rozwiazania..., s. 95-96.

12 Ibidem.
} 
wyjściem z sytuacji byłaby nowelizacja art. $109^{1} \S 1$ k.c. usuwająca istniejące w tym zakresie wątpliwości (przez pozostawienie wyłącznie terminu „rejestr” bez dodatku „przedsiębiorców”, czy też przez dodanie słowa „właściwego”). W świetle art. 25 ust. 1 pkt 11 ustawy o swobodzie działalności gospodarczej wpisowi do Centralnej Ewidencji i Informacji o Działalności Gospodarczej podlegają jednak dane pełnomocnika upoważnionego do prowadzenia spraw przedsiębiorcy wraz ze wskazaniem zakresu spraw, które obejmuje dane pełnomocnictwo, o ile przedsiębiorca udzielił pełnomocnictwa i zgłosił informację o jego udzieleniu we wniosku o wpis do CEIDG. Pojęciem „pełnomocnictwo” należałoby objąć również prokurę, będącą w istocie jego szczególnym rodzajem. Przez brak wyraźnego wskazania w przepisach na prokurenta został utrzymany stan prawny wskazujący na niezrozumiały rozdźwięk przepisów prawa prywatnego i publicznego, który należałoby usunąć ${ }^{13}$. Potwierdzeniem możliwości udzielenia prokury przez osoby fizyczne prowadzące działalność gospodarczą jest ponadto brzmienie art. 1097 $\S 4$ k.c., zgodnie z którym prokura nie wygasa wraz ze śmiercią przedsiębiorcy. Oczywistym jest, iż może to dotyczyć wyłącznie osób fizycznych. Pomimo tego, co zostało zaprezentowane i omówione powyżej, w doktrynie nadal funkcjonują różne, czasem nawet skrajne, stanowiska na ten temat. Niemniej wydaje się słusznym, z czym się w pełni zgadzam, przyjęcie za właściwe poglądu dominującego w doktrynie, mianowicie za dopuszczeniem możliwości udzielenia prokury przez przedsiębiorców indywidualnych podlegających obowiązkowi wpisu do CEIDG.

Przedmiotem rozważań warto uczynić także wspólników spółki cywilnej, będących osobami fizycznymi, którzy w zakresie prowadzonej przez siebie działalności gospodarczej również są przedsiębiorcami. Logicznym wydaje się, iż mają oni prawo udzielenia prokury. Nie ma tego prawa natomiast spółka cywilna, ponieważ jest tylko umową cywilnoprawną, a nie podmiotem prawa. W tej sytuacji skutki prawne wynikające z czynności prawnych podejmowanych przez prokurenta, ustanowionego przez wspólnika spółki cywilnej, wywołują skutki bezpośrednio w jego sferze prawnej, a nie samej spółki czy pozostałych wspólników, nawet jeśli dotyczyłyby wspólnie prowadzonego przedsiębiorstwa.

Drugim niejasno sformułowanym wyrażeniem, który wymaga skonkretyzowania jest określenie „podlegający obowiązkowi wpisu”. Wątpliwości krążą tutaj wokół kwestii, czy chodzi o samo wypełnianie przesłanki podlegania obowiązkowi wpisu, bez względu na jego dokonanie, czy również z dopełnieniem tej czynności. Wspomniana wcześniej K. Kopaczyńska-Pieczniak stoi na stanowisku, iż legitymację czynną do udzielenia prokury mają przedsiębiorcy podlegający na mocy przepisów ustawy o Krajowym Rejestrze Sądowym lub innej ustawy obowiązkowi wpisu do Krajowego Rejestru Sądowego albo do innego

13 Z. Gawlik [et. al.], Kodeks cywilny. Komentarz, t. 1: Część ogólna, wyd. 2, Warszawa 2012 . 
szeroko rozumianego rejestru, bez względu na to, czy faktycznie taki wpis został dokonany ${ }^{14}$. Problem pojawia się głównie w kwestii spółek kapitałowych w organizacji (spółki z ograniczoną odpowiedzialnością i spółki akcyjnej), które mogą podjąć i prowadzić działalność gospodarczą we własnym imieniu zanim zostaną wpisane do rejestru. D. Wajda, podobnie jak K. Kopaczyńska-Pieczniak, opowiada się za stanowiskiem dopuszczającym reprezentację takiej spółki przez prokurenta ${ }^{15}$. Przeciwnego zdania, które osobiście podzielam, są A. Kidyba czy J. Szwaja, którzy twierdzą, iż nie przekonują argumenty przemawiające za dopuszczalnością udzielenia prokury przez kapitałową spółkę w organizacji, gdyż jest to tylko „upodmiotowiona faza organizacyjna” spółki kapitałowej, która nie ma jeszcze ostatecznie ukształtowanej struktury organizacyjnej. Na tym etapie nie podlegają ujawnieniu nawet dane osób uprawnionych do reprezentacji. Ponadto, w odróżnieniu od przedsiębiorcy indywidualnego, który jest wpisany w ewidencji, spółka kapitałowa w organizacji jest bytem przejściowym i z tego powodu „niepewnym”. Dopuszczenie możliwości udzielenia przez nią prokury stanowiłoby ryzyko dla osób trzecich i dla pewności obrotu gospodarczego ${ }^{16}$.

Na koniec rozważań dotyczących legitymacji czynnej do udzielenia prokury, dla kompleksowego ujęcia tego zagadnienia, należy wspomnieć o osobach (podmiotach), które nie mogą udzielić prokury. Są to osoby fizyczne prowadzące działalność gospodarczą w zakresie rolnictwa lub świadczenia usług agroturystycznych, które choć są przedsiębiorcami w świetle art. $43^{1}$ k.c., to nie podlegają obowiązkowi wpisu ani do KRS-u ani do CIDG, a tym samym nie mogą udzielić prokury. Innym przykładem są przedsiębiorcy znajdujący się w stanie likwidacji lub wobec których ogłoszono upadłość. Wniosek taki wynika pośrednio z przepisu art. $109^{7} \S 2$ k.c., który stanowi o wygaśnięciu prokury wraz z otwarciem likwidacji lub ogłoszeniem upadłości. Celem ustawodawcy było więc świadome wyłączenie możliwości ustanowienia prokurenta przez przedsiębiorcę znajdującego się $w$ jednej $z$ wymienionych wyżej sytuacji. Potwierdzeniem tego jest między innymi uchwała Sądu Najwyższego z dnia 21 lipca 2006 roku $^{17}$ wydana w odpowiedzi na pytanie Sądu Okręgowego w Gliwicach, a pytanie brzmiało: „Czy przewidziane w art. $109^{7} \S 2$ k.c. wygaśnięcie prokury wskutek ogłoszenia upadłości przedsiębiorcy dotyczy tylko ogłoszenia upadłości obejmującej likwidację majątku upadłego, czy również upadłości z możliwością zawarcia układu?" oraz „Czy jest dopuszczalne ustanowienie prokury przez upadłego, co do którego ogłoszono upadłość z możliwością zawarcia układu, pozostawiając mu za-

14 Ibidem.

15 D. Wajda, Prokura - problemy praktyczne, „Przegląd Prawa Handlowego” 2008, nr 6, s. 40.

16 J. Szwaja, [w:] S. Sołtysiński [et al.], op. cit., s. 495.

17 Uchwała Sądu Najwyższego z dnia 21 lipca 2006 roku, sygn. akt III CZP/45/06, LEX nr 188833 . 
rząd własny mieniem wchodzącym do masy upadłości?”. Sąd Najwyższy podjął uchwałę, iż z chwilą ogłoszenia upadłości prokura wygasa, a nowa nie może być ustanowiona.

Nie wgłębiając się w szczegóły dotyczące stanu faktycznego, w przedmiotowej sprawie chodziło o ustalenie, czy spółka, w stosunku do której ogłoszono upadłość z możliwością zawarcia układu, może ustanowić prokurenta. Sąd Okręgowy w Gliwicach stanął na stanowisku, iż tylko ogłoszenie upadłości obejmującej likwidację majątku dłużnika powoduje wygaśnięcie prokury, natomiast upadłość z możliwością zawarcia układu nie powoduje wygaśnięcia prokury.

Sąd Najwyższy w uzasadnieniu prawnym zwrócił uwagę na podstawową kwestię wiążącą się z pytaniem, czy określenie „ogłoszenie upadłości” dotyczy wszystkich rodzajów upadłości przewidzianej w ustawie z dnia 28 lutego 2003 roku, a tym samym czy prokura zawsze wygasa w razie ogłoszenia upadłości. SN przypomniał, iż skutkiem ogłoszenia upadłości likwidacyjnej jest zawsze odebranie upadłemu możliwości zarządzania jego majątkiem (art. 75 ust. 1), natomiast w przypadku upadłości, której celem jest zawarcie układu upadły może być pozbawiony zarządu albo sąd może ustanowić zarząd sprawowany przez upadłego, tzw. zarząd własny (art. 76 ust. 1). Jeżeli dopuszcza się zarząd własny upadłego, to i tak jest on wykonywany pod nadzorem nadzorcy sądowego, co oznacza, że jeżeli ustawa nie stanowi inaczej, upadły może dokonywać samodzielnie tylko czynności zwykłego zarządu, a dla czynności przekraczających zwykły zarząd wymagana jest zawsze zgoda nadzorcy sądowego (art. 76 ust. 3). Udzielenie prokury jest niewątpliwie, zdaniem Sądu Najwyższego, czynnością przekraczającą zwykły zarząd, więc nawet gdyby dopuścić istnienie prokury w trakcie trwania upadłości, to byłoby to możliwie tylko wtedy, gdy nadzorca sądowy wyraziłby na to swoją zgodę. Wnioski wynikające z wykładni językowej i systemowej art. $109^{7}$ k.c. pozostają w zgodzie z funkcją prokury i postępowania upadłościowego. Prokura jest instytucją ułatwiającą przedsiębiorcy prowadzenie przez niego zarządu przedsiębiorstwem, więc jeżeli jest on pozbawiony prawa zarządu, to nie może istnieć pełnomocnictwo uprawniające inne osoby niż wskazane w przepisach ustawy - Prawo upadłościowe i naprawcze (syndyk, zarządca oraz nadzorca sądowy) do sprawowania zarządu majątkiem upadłego. W sytuacji, w której postanowienie o ogłoszeniu upadłości mającej na celu zawarcie układu dopuszcza zarząd własny upadłego, istnienie prokury także jest wyłączone.

\section{ZAKRES UMOCOWANIA}

Rozważaniom poddana zostanie również strona przedmiotowa prokury. Zakres umocowania prokurenta został określono ustawowo. Obejmuje on umocowanie do dokonywania czynności sądowych i pozasądowych związanych z prowadzeniem przedsiębiorstwa. Tak określony zakres prokury sięga do Kodeksu 
handlowego, z tą różnicą, iż w art. 61 k.h. użyto terminu ,upoważnienie”. Obecnie Kodeks cywilny posługuje się pojęciem „umocowanie”, co należy uznać za pozytywną i merytorycznie lepszą zmianę redakcyjną przepisu.

Zakres umocowania prokurenta jest szeroki. Obejmuje wspomniane już czynności sądowe oraz pozasądowe. Bez znaczenia jest natomiast, czy chodzi o czynności zwykłego zarządu, czy przekraczające zwykły zarząd. Można zaryzykować stwierdzenie, iż umocowanie to jest szersze nawet od najszerszego pełnomocnictwa ogólnego, które obejmuje wyłącznie czynności zwykłego zarządu.

Jednym z kryteriów wyznaczających zakres prokury jest związek czynności, do których umocowany jest prokurent (tj. sądowych i pozasądowych) z prowadzeniem przedsiębiorstwa. W doktrynie pojawiły się rozbieżności co do znaczenia pojęcia „przedsiębiorstwo". Przeważa pogląd o rozumieniu tego pojęcia w znaczeniu funkcjonalnym ${ }^{18}$. W Kodeksie cywilnym występuje znaczenie przedmiotowe. Przedsiębiorstwo w rozumieniu art. $55^{1}$ k.c. jest zorganizowanym zespołem składników niematerialnych i materialnych przeznaczonym do prowadzenia działalności gospodarczej. W doktrynie przeważa pogląd, iż „przedsiębiorstwo” w znaczeniu funkcjonalnym oznacza działalność gospodarczą prowadzoną przy wykorzystaniu przedsiębiorstwa w rozumieniu art. $55^{1}$ k.c. Można więc wnioskować, iż nie każda działalność gospodarcza jest przedsiębiorstwem w znaczeniu funkcjonalnym, lecz tylko taka, która jest prowadzona przy wykorzystaniu przedsiębiorstwa $\mathrm{w}$ znaczeniu przedmiotowym ${ }^{19}$.

Niezależnie od przyjętego znaczenia terminu ,przedsiębiorstwo” pozostaje do wyjaśnienia kwestia związana z granicami umocowania prokurenta w związku z działalnością zawodową. Mając na uwadze to, co do tej pory zostało przedstawione, można stwierdzić, iż zorganizowany zespół składników niematerialnych i materialnych przeznaczony do prowadzenia działalności zawodowej nie jest przedsiębiorstwem w rozumieniu art. $55^{1}$ k.c. Podmiot prowadzący taką działalność, choć ma status przedsiębiorcy, nie mógłby udzielić prokury. Niemniej, analizując art. $43^{1}$ k.c., w którego treści znalazło się miejsce dla pojęcia ,działalność zawodowa”, można przyjąć znaczenie „działalności gospodarczej” w sensie largo. Tym samym przedsiębiorca prowadzący taką działalność mógłby udzielić prokury. Za takim rozwiązaniem przemawia cel samej konstrukcji przepisów nastawiony na obrót profesjonalny oraz fakt, iż pochodzą one $\mathrm{z}$ czasów jeszcze przed dokonaniem w Kodeksie cywilnym rozróżnienia na działalność gospodarczą i działalność zawodową.

Prokurent umocowany do działania może dokonywać czynności związanych z działalnością gospodarczą przedsiębiorcy w dwóch obszarach. Pierwszy z nich

18 L. Moskwa, Nowe przepisy o prokurze, „Rejent” 2001, nr 9, s. 33

19 S. Rudnicki, [w:] S. Dmowski, S. Rudnicki, Komentarz do Kodeksu cywilnego. Ksiega pierwsza. Czesść ogólna, Warszawa 2007, s. 441. 
dotyczy czynności sądowych i swym zakresem obejmuje reprezentowanie przedsiębiorcy w postępowaniu przed sądami powszechnymi, administracyjnymi, Sądem Najwyższym, sądami polubownymi, a także przed organami administracji samorządowej i rządowej. Jest to sfera stosunków zewnętrznych (reprezentacji). Prokurent składa własne oświadczenie woli, ale działa w imieniu i na rzecz mocodawcy. Jego czynności wywołują bezpośredni skutek prawny dla mocodawcy. Oznacza to, iż prokurent należy do podmiotów reprezentujących przedsiębiorcę. Sposób reprezentacji zależy od woli przedsiębiorcy. Art. $109^{4}$ k.c. stanowi, iż prokura może być udzielona kilku osobom łącznie (prokura łączna) lub oddzielnie. Mocodawca może więc ustanowić prokurę samoistną, umocowującą prokurenta do samodzielnego składania oświadczeń woli, lub prokurę łączną, zobowiązującą prokurenta do współdziałania z inną osobą lub osobami. Prokurent może współdziałać nie tylko z drugim prokurentem, ale także z pełnomocnikiem czy nawet z członkiem zarządu.

Wokół kwestii zasady reprezentacji łącznej przez członka zarządu z prokurentem istnieje wiele sprzeczności. Kontrowersje wzbudziło słynne już orzeczenie Sądu Najwyższego z dnia 27 kwietnia 2001 roku, w którym Sąd Najwyższy w odpowiedzi na pytanie Sądu Okręgowego stwierdził, że dopuszczalne jest udzielenie prokury jednej osobie, z tym jednak zastrzeżeniem, iż może ona działać tylko łącznie z członkiem zarządu spółki albo ze wspólnikiem ${ }^{20}$. W praktyce oznacza to możliwość udzielenia prokury łącznej jednej osobie. W następstwie tego orzeczenia pojawiło się wiele glos zarówno aprobujących, jak i krytycznych. Kwestią, która nie budzi wątpliwości jest fakt, iż prokura jest szczególnego rodzaju pełnomocnictwem oraz że może być udzielona tylko jednej osobie lub kilku osobom. W tym ostatnim przypadku możemy mieć do czynienia z sytuacją, kiedy udzielono prokury wszystkim tym osobom łącznie (prokura łączna) lub każdej z tych osób oddzielnie (prokura samodzielna). Oznacza to, że w przypadku udzielenia prokury przez spółkę z ograniczoną odpowiedzialnością np. dwóm osobom, mogą one działać oddzielnie (samodzielnie), czyli de facto mamy do czynienia z dwoma samodzielnymi prokurentami. Natomiast jeśli zarząd udzieliłby tym dwóm osobom prokury łącznie (słowo kluczowe w tej sytuacji), mogłyby one skutecznie dokonać czynności prawnej w imieniu spółki wyłącznie wspólnie. Mając te wiadomości na względzie, widać wyraźnie, że Sąd Najwyższy we wspomnianym wyżej orzeczeniu ograniczył uprawnienia prokurenta samoistnego, wiążąc go obowiązkiem współdziałania z członkiem zarządu (spółka kapitałowa) albo ze wspólnikiem (spółka osobowa). Doktryna nazwała ten rodzaj reprezentacji reprezentacją ,niewłaściwą” lub „mieszaną”. W mojej opinii powyższe orzeczenie jest silnie powiązane $\mathrm{z}$ art. $205 \S 1$ k.s.h., który stanowi, iż w przypadku zarządu wieloosobowego sposób reprezentacji określa umowa spółki. Jeżeli umowa

20 Uchwała Sądu Najwyższego z dnia 27 kwietnia 2001 roku, sygn. akt III CZP 6/01, LEX. 
milczy na ten temat, do składania oświadczeń w imieniu spółki wymagane jest współdziałanie dwóch członków zarządu albo jednego członka zarządu łącznie z prokurentem. $Z$ kolei $\S 3$ tego artykułu stanowi, iż sytuacja powołania zarządu wieloosobowego spółki nie wyłącza możliwości ustanowienia prokury jednoosobowej lub łącznej i nie ogranicza praw prokurentów wynikających z przepisów o prokurze.

Jak słusznie stwierdził Sąd Najwyższy w powołanym wyżej orzeczeniu, z regulacji art. $205 \S 1$ k.s.h. wynika szereg konsekwencji. Po pierwsze, posiadanie przez spółkę kapitałową wieloosobowego zarządu, którego członkowie mają kompetencje reprezentacji łącznej, nie ogranicza możliwości ustanowienia prokury łącznej. Ponadto spółka może udzielić nie tylko prokury łącznej, ale i oddzielnej, a także powołać tylko jednego prokurenta.

Po drugie, sytuacja reprezentowania spółki kapitałowej przez członka zarządu łącznie z prokurentem nie ogranicza uprawnień prokurentów wynikających z przepisów o prokurze. Oznacza to, że łączna reprezentacja spółki przez członka zarządu z drugim członkiem zarządu lub prokurentem nie pozbawia osoby, której udzielono prokury, oddzielnej możliwości skutecznego samodzielnego działania w imieniu spółki w charakterze prokurenta. Tak samo jest w przypadku, gdy udzielono prokury łącznej - prokurenci nie są zobowiązani do współdziałania z członkiem zarządu.

Po trzecie, w przypadku wyżej opisanej reprezentacji łącznej (mieszanej) członek zarządu może współdziałać nie tylko z prokurentem samodzielnym, ale z każdym prokurentem, tj. również tym, któremu udzielono prokury łącznej. Nasuwa to wniosek o istnieniu różnicy i oddzieleniu sytuacji, w której prokurent działa w ramach reprezentacji mieszanej spółki od sytuacji, w której działa w imieniu spółki samodzielnie lub z innymi prokurentami. Reaumując, oznacza to, że gdy członek zarządu ma działać łącznie z prokurentem, to należy przyjąć, idąc za Sądem Najwyższym, że wystarcza współdziałanie z każdym prokurentem, bez względu na rodzaj udzielonej mu prokury. Ponadto Sąd Najwyższy stwierdził, iż przepisy art. $205 \S 1$ k.s.h. oraz art. $373 \S 3$ k.s.h. (spółki kapitałowe) należy w drodze analogii stosować również do reprezentacji spółek osobowych.

Wracając do tezy poddanego analizie orzeczenia, pytanie Sądu Okręgowego dotyczyło możliwości udzielenia prokury określonej osobie z zastrzeżeniem, iż może ona działać wyłącznie z członkiem zarządu spółki kapitałowej lub wspólnikiem spółki osobowej. W doktrynie istnieje spór odnośnie do tej kwestii. Reprezentowane są bowiem dwa przeciwstawne stanowiska (aprobujące i wykluczające taką możliwość). Sąd Najwyższy w przedmiotowym orzeczeniu dopuścił jednak możliwość udzielenia prokury z opisanym wyżej zastrzeżeniem. Swoje stanowisko uzasadnił między innymi w ten sposób: mimo że prokura łączna, w swojej istocie, zakłada udzielenie umocowania łącznie dwóm lub więcej osobom (reprezentacja łączna), przy czym każda z nich jest prokurentem, a udzielenie prokury konkretnej 
osobie z zastrzeżeniem współdziałania z członkiem zarządu lub wspólnikiem spółki jest czym innym (reprezentacja mieszana), bowiem tutaj prokurentem jest tylko ta pierwsza osoba, nie przesądza to o niedopuszczalności takiego rozwiązania, gdyż nie uszczupla to uprawnień prokurenta. Ponadto SN powołał się w uzasadnieniu również na kwestie praktyczne przemawiające za takim rozwiązaniem.

Sąd Najwyższy w uchwale z dnia 24 lipca 2013 roku stwierdził, iż prokurent występuje w roli pełnomocnika procesowego strony w rozumieniu art. 88 Kodeksu postępowania cywilnego (k.p.c.). Sam także może udzielić pełnomocnictwa (w tym dalszego, bez specjalnego dodatkowego upoważnienia) osobom wymienionym w art. $87 \S 2$ k.p.c. ${ }^{21}$ Wśród czynności z tej sfery można wymienić dla przykładu: wnoszenie i cofnięcie pozwów, wnoszenie środków odwoławczych, wspomniane już ustanawianie i odwoływanie pełnomocników procesowych oraz zawieranie umów o arbitraż.

Drugi obszar działań, do których umocowany jest prokurent, to sfera czynności pozasądowych, a więc czynności o charakterze materialnoprawnym. Chodzi tutaj nie tylko o czynności prawne (pozostające w związku z działalnością gospodarczą przedsiębiorcy), ale też o inne czynności zbliżone do oświadczeń woli. Ogólnie mówiąc, są to czynności związane z funkcjonowaniem przedsiębiorstwa. Znajduje się wśród nich przede wszystkim zawieranie umów cywilnoprawnych z zakresu prawa handlowego, gospodarczego, prawa własności intelektualnej czy prawa pracy. W postanowieniu z dnia 30 października 2008 roku Sąd Najwyższy stwierdził między innymi, że prokura obejmuje umocowanie do zapisu na sąd polubowny: „W ramach prokury samoistnej prokurent jest umocowany do zawarcia w imieniu przedsiębiorcy umowy (z ograniczeniem przewidzianym w art. 1093 k.c.), a w konsekwencji jego pełnomocnictwo, zgodnie z art. 1167 k.p.c., obejmuje również uprawnienie do zawarcia umowy zawierającej zapis na sąd polubowny w zakresie sporów wynikających z tej umowy"22.

Podsumowując, opisane wyżej czynności, do których umocowany jest prokurent, należą do zakresu prokury, o ile związane są z prowadzeniem przedsiębiorstwa. Chodzi tutaj o czynności związane z nim zarówno bezpośrednio, jak i pośrednio. Generalne wskazanie na czynności związane z prowadzeniem przedsiębiorstwa, bez uściślenia, jakiego przedsiębiorstwa dotyczą, przemawia za wnioskiem, iż prokura obejmuje umocowanie związane z dokonywaniem czynności dotyczących w ogólności przedsiębiorstwa, a nie tylko przedsiębiorstwa mocodawcy ${ }^{23}$.

21 Uchwała Sądu Najwyższego z dnia 24 lipca 2013 roku, sygn. akt III CZP 45/13, LEX nr 1350230.

22 Postanowienie Sądu Najwyższego z dnia 30 października 2008 roku, sygn. akt II CSK 263/08, LEX nr 508836.

${ }_{23}$ J. Strzebińczyk, [w:] Kodeks cywilny. Komentarz, pod red. E. Gniewka, wyd. 4, Warszawa 2011, s. 258. 


\section{WYŁĄCZENIA}

Warto w tym miejscu wspomnieć o czynnościach, które zostały ustawowo wyłączone z zakresu umocowania prokurenta. Mowa o czynnościach enumeratywnie wyliczonych $\mathrm{w}$ art. $109^{3} \mathrm{k}$.c., tj. zbyciu przedsiębiorstwa, dokonywaniu czynności prawnych, na podstawie których następuje oddanie przedsiębiorstwa do czasowego korzystania oraz zbywaniu i obciążaniu nieruchomości. Nie oznacza to, że prokurent nie może ich dokonać. Potrzebuje jednak w każdym przypadku pełnomocnictwa szczególnego.

Wyłączone z umocowania prokurenta są także czynności należące do sfery prowadzenia spraw, a więc z zakresu stosunków wewnętrznych przedsiębiorcy. Nie mieszczą się w granicach prokury czynności organizacyjne związane z funkcjonowaniem przedsiębiorcy jako podmiotu prawa oraz czynności niezwiązane z prowadzeniem przedsiębiorstwa. Możemy do nich zaliczyć dla przykładu: czynności z zakresu prywatnych spraw przedsiębiorcy (sprawy osobiste, sprawy z zakresu prawa rodzinnego), inne niezwiązane z prowadzeniem przedsiębiorstwa czy w końcu mające za cel zakończenie prowadzenia przedsiębiorstwa ${ }^{24}$.

Nasuwa się pytanie, co w sytuacji, gdy prokurent dokona czynności wykraczającej poza jego umocowanie? Wówczas w drodze analogii mają zastosowanie przepisy o pełnomocnictwie, a konkretnie art. 103 i 104 k.c. Dotyczą one sytuacji, kiedy pełnomocnik działa bez umocowania albo z przekroczeniem jego zakresu (falsus procurator). Innym zdarzeniem jest sytuacja, kiedy prokurent dokonuje czynności mieszczącej się co prawda w zakresie umocowania, opierając się jednak na innej podstawie do reprezentowania przedsiębiorcy. Sąd Najwyższy w wyroku z dnia 29 listopada 2007 roku uznał, iż umowa podpisana w imieniu spółki z ograniczoną odpowiedzialnością przez osobę umocowaną do jej zawarcia jako prokurent, działającą jako zarząd tej spółki, lecz niewchodzącą w jego skład, wiąże spółkę i jej kontrahenta ${ }^{25}$.

Na koniec warto wspomnieć o jeszcze jednym „ograniczeniu”. Nie można bowiem ograniczyć prokury ze skutkiem prawnym wobec osób trzecich, chyba że przepis szczególny stanowi inaczej. Norma zawarta w art. $109^{1} \S 2$ k.c. ma charakter bezwzględnie obwiązujący. Oznacza to, iż nie jest możliwe zastrzeżenie umowne, iż prokura zostanie udzielona, ale z zastrzeżeniem ograniczenia jej ze skutkiem zewnętrznym. Takie zastrzeżenie jest bezskuteczne wobec osób trzecich. Wywołuje natomiast skutki w stosunkach wewnętrznych. Wówczas czynność dokonana przez prokurenta $\mathrm{z}$ naruszeniem ograniczenia jest ważna, może się jednak wiązać z kwestią odpowiedzialności wobec mocodawcy za takie działanie. Odpo-

24 J. Szwaja, [w:] S. Sołtysiński [et al.], op. cit., s. 484.

25 Wyrok Sądu Najwyższego z dnia 29 listopada 2007 roku, sygn. akt III CSK 169/07, LEX nr 471369. 
wiedzialność może mieć charakter majątkowy w postaci obowiązku naprawienia szkody lub może skutkować odwołaniem prokurenta ${ }^{26}$. Jedynym wyjątkiem, kiedy takie wewnętrzne ograniczenie mogłoby być skuteczne wobec osób trzecich, jest sytuacja wystąpienia zmowy (koluzji) między prokurentem a osobą trzecią. Chodzi o sytuację, kiedy osoba trzecia świadomie i celowo dokonuje czynności z prokurentem przekraczającym ustanowione ograniczenia i działa przy tym ewidentnie na szkodę mocodawcy ${ }^{27}$.

Czym innym jest prokura oddziałowa. Jest o niej mowa w art. $109^{5}$ k.c. Prokurę można ograniczyć do zakresu spraw wpisanych do rejestru oddziału przedsiębiorstwa. Nie jest to de facto ograniczenie zakresu umocowania prokurenta jako takiego. Ograniczony tutaj jest zakres spraw, a nie samo umocowanie, ponieważ nadal obejmuje ono czynności sądowe i pozasądowe, lecz ograniczone do zakresu spraw oddziału przedsiębiorstwa.

\section{PODSUMOWANIE}

Prokura jest pełnomocnictwem udzielanym przede wszystkim w ramach funkcjonowania spółek handlowych, a więc podmiotów, które prowadzą działalność gospodarczą podlegającą wpisowi do rejestru przedsiębiorców. Jest to zatem rodzaj pełnomocnictwa związany nierozerwalnie z działalnością gospodarczą. Należy jednak pamiętać, że prokury udzielić mogą także osoby fizyczne będące przedsiębiorcami. Jednocześnie instytucję prokury charakteryzują szczególne cechy. Może jej udzielić tylko przedsiębiorca rejestrowy, upoważnia do czynności związanych z prowadzeniem przedsiębiorstwa czy to, że zakres umocowania wyznacza ustawa. Prokura zawiera umocowanie do działania w sferze zewnętrznej przedsiębiorcy w sprawach związanych z prowadzeniem przedsiębiorstwa. Wszystko to potwierdza, iż prokura jest instytucją zawierającą w sobie cechy pełnomocnictwa $z$ dodatkowymi elementami, które sprawiają, iż jest ona pełnomocnictwem szczególnego rodzaju, szerszym od pełnomocnictwa ogólnego.

\section{BIBLIOGRAFIA}

Allerhard A., Kodeks handlowy. Komentarz, t. 1, Lwów 1935.

Dekret z dnia 7 lutego 1919 roku o rejestrze handlowym (Dz.U. z 1919 roku, nr 14, poz. 164).

Gawlik Z., Janiak A., Jedliński A., Kidyba A. (red. nauk.), Kopaczyńska-Pieczniak K., Niezbecka E., Sokołowski T., Kodeks cywilny. Komentarz, t. 1: Część ogólna, wyd. 2, Warszawa 2012.

Kidyba A., Nowe rozwiazania kodeksu cywilnego dotyczace prokury, [w:] Państwo - Prawo - Myśl prawnicza. Prace dedykowane prof. G.L. Seidlerowi w dziewięćdziesiąta rocznicę urodzin, pod red. A. Korobowicza, Lublin 2003.

26 A. Allerhard, Kodeks handlowy. Komentarz, t. 1, Lwów 1935, s. 105.

27 Ibidem. 
Kidyba A., Prawo handlowe, wyd. 13, Warszawa 2013.

Moskwa L., Nowe przepisy o prokurze, „Rejent” 2001, nr 9.

Postanowienie Sądu Najwyższego z dnia 30 października 2008 roku, sygn. akt II CSK 263/08, LEX nr 508836.

Rozporządzenie Prezydenta Rzeczypospolitej Polskiej z dnia 27 czerwca 1934 roku - Kodeks handlowy (Dz.U. z 1934 roku, nr 57, poz. 502).

Rudnicki S., [w:] S. Dmowski, S. Rudnicki, Komentarz do Kodeksu cywilnego. Księga pierwsza. Część ogólna, Warszawa 2007.

Strzebińczyk J., [w:] Kodeks cywilny. Komentarz, pod red. E. Gniewka, wyd. 4, Warszawa 2011.

Szwaja J., [w:] S. Sołtysiński, A. Szajkowski, A. Szumański, J. Szwaja, Kodeks spółek handlowych. Komentarz, t. 5, wyd. 2, Warszawa 2004.

Szwaja J., Ustanowienie, udzielenie oraz odwołanie prokury przez spółkę handlowa, „Prawo Spółek” 2003, $\mathrm{nr} 7-8$.

Uchwała Sądu Najwyższego z dnia 27 kwietnia 2001 roku, sygn. akt III CZP 6/01, LEX.

Uchwała Sądu Najwyższego z dnia 21 lipca 2006 roku, sygn. akt III CZP/45/06, LEX nr 188833.

Uchwała Sądu Najwyższego z dnia 24 lipca 2013 roku, sygn. akt III CZP 45/13, LEX nr 1350230.

Ustawa z dnia 10 maja 1897 roku - Niemiecki kodeks handlowy (Handelsgesetzbuch).

Ustawa z dnia 20 sierpnia 1997 roku o Krajowym Rejestrze Sądowym (t.j. Dz.U. z 2015 roku, poz. 4).

Ustawa z dnia 15 września 2000 roku - Kodeks spółek handlowych (t.j. Dz.U. z 2015 roku, poz. 4).

Ustawa z dnia 14 lutego 2003 roku o zmianie ustawy - Kodeks cywilny oraz niektórych innych ustaw (Dz.U. z 2003 roku, nr 49, poz. 408).

Wajda D., Prokura - problemy praktyczne, „Przegląd Prawa Handlowego” 2008, nr 6.

Wyrok Sądu Najwyższego z dnia 29 listopada 2007 roku, sygn. akt III CSK 169/07, LEX nr 471369.

\section{SUMMARY}

Commercial representation is a power of attorney granted mainly in commercial companies, that is entities which run business activities subject to entry in the commercial register. It is a type of power of attorney, connected inseparably with business activities. It should be stressed, however, that commercial representation may also be used by physical persons who are entrepreneurs. At the same time, the institution of commercial representation has special characteristics. It may be used only by registered entrepreneurs, it grants powers to perform activities related to running the enterprise, and the scope of powers is determined by law. Commercial representation contains the power to act in the external relations of the entrepreneur in matters related to running the enterprise. All this confirms that commercial representation is an institution combining characteristics of a power of attorney with some additional elements which make it a special type of power of attorney, wider than the general power of attorney.

Keywords: commercial representation; power of attorney; authorisation; register; entrepreneur 